\title{
Catalogue of the Acropolis Museum, Vol. II: Sculpture and Architectural Fragments. By Stanley Casson. With a Section upon the Terracottas, by Dorothy Brooke
}

\section{Stephen B. Luce}

To cite this article: Stephen B. Luce (1921) Catalogue of the Acropolis Museum, Vol. II: Sculpture and Architectural Fragments. By Stanley Casson. With a Section upon the Terracottas, by Dorothy Brooke, The Art Bulletin, 4:2, 76-79, DOI: 10.1080/00043079.1921.11409718

To link to this article: http://dx.doi.org/10.1080/00043079.1921.11409718

\section{Published online: 22 Dec 2015.}

Submit your article to this journal ¿ 
whether one agrees with them or not. Thus Hambidge's theory is of value, if for no other reason, for the discussion it has provoked ; and Reichhold's book is equally valuable for bringing to the attention of students the vulnerability of some of our cherished theories, and for the detailed study of the human figure and its anatomy as shown on the vase-paintings. To me it is one of the most important studies of the subject that has appeared in recent times, and is worthy of consideration by teachers of art as a text-book on the technique of Greek vases.

\section{Stephen B. Luce}

Catalogue of the Acropolis Museum, Vol. II: Sculpture and Architectural Fragments. By Stanley Casson. With a Section upon the Terracottas, by Dorothy Brooke. X, 459 PP. Cambridge (England), Cambridge University Press, 1921.

After nine years of waiting, the second volume of the Acropolis Museum catalogue has at last appeared. This delay, as stated in the preface, is due to the Great War. The first volume was from the pen of the lamented Guy Dickins, who was killed in action early in the war, and in whose untimely death, as Casson so truly says, "Archæology has suffered an irreparable loss." But Dickins had never intended, it seems, to continue with the catalogue. His first volume merely blazed a trail for others to follow. And so we find that Casson had prepared his manuscript as early as the spring of 1914 , at which time it was read by Dickins. It was in its final form and had been sent to the press just before war broke out. The section on terracottas by Mrs. Brooke, who, as Miss Dorothy Lamb, was well known to many archæologists in this country, was also written before the war, when she was in residence as a student in the British School at Athens.

Both sections of the catalogue are preceded by short introductions (pp. 1-37, 317-343). The introduction to the sculpture section discusses the different objects, and gives facts not easily to be inserted in the body of the catalogue. It takes up the information obtainable from the fragments

'See the able articles opposing dynamic symmetry by Carpenter, $A$. J.A., XXV, 1921, pp. 18-36, and Blake, The Art Bulletin, III, 1921, pp. 107-127. 
from the Parthenon, the Nike temple, and the Erechtheum, discusses the various independent sculptures found on the Acropolis, and gives a working chronology of these objects. The architectural fragments and inscriptions are also briefly noticed. In the introduction to the section on terracottas, Mrs. Brooke takes up the history of the collection, the chronology, subjects, clay, and costumes, and ends with an abridged bibliography. In my opinion, these introductions are of the greatest value, and every scientific catalogue of a collection should be preceded by something of this sort.

The catalogue proper of the sculpture and architectural fragments is divided into approximately the divisions indicated by the introduction: I, Fragments from the Pediments of the Parthenon; II, Remains of the Metopes of the Parthenon; III, Remains of the Frieze of the Parthenon; IV, The Balustrade of the Temple of Athena Nike; V, Remains of the Frieze of the Erechtheum; VI, Various Sculptures; VII, Various Fragments of Uncertain Attribution; VIII, Objects in the Courtyard; IX, Architectural Fragments (in which architectural terracottas are included); X, Painted Pinax; XI, Fragments from Decorated Pithoi.

Each specimen is given an adequate description, with measurements, and references to former publications and descriptions, where any exist. The more important objects are illustrated by small photographs. One might wish for more of these photographs; for, in the ideal scientific catalogue (an ideal that is rarely, if ever, attained!) an illustration of each specimen listed would be published. In this case, however, it would not be practicable to reproduce every one of the small fragments which form such a large proportion of the items. Many pieces, nevertheless, evidently of some importance, are not published, which is a matter to be deplored.

The painted pinax, which is the subject of section $X$ of the catalogue, is that famous piece, often published, of a warrior running toward the left, which is attributed by Hoppin to the vase-painter Euthymides (Euthymides and His Fellows, p. 89). In discussing this object, Casson shows that the subject of Greek vases is one with which he is not 
entirely familiar. He compares the pinax to a vase "by Kachrylion." There are two mistakes in these two words. In the first place, Chachrylion should be spelt with an initial $C h$, as the vase-painter's name in the Greek is spelt with a $X$. In the second place, Beazley has shown conclusively that Chachrylion was only a potter, and that his vases were painted by different hands; he divides them about evenly between Oltos and the "Hermaios painter." Beazley's conclusions have been accepted by nearly all the best vase experts, and Casson should not ignore them.

In discussing Hoppin's attribution of the pinax, with which he disagrees, Casson calls Euthymides an artist of the "Epiktetan cycle." But in style and technique, Euthymides is of a later period and is a contemporary of Euphronios, to whom he refers in a famous inscription on a vase in Munich, the existence of which must have been forgotten by Casson. He is therefore also a contemporary of Chachrylion, who was potter for Euphronios on at least one vase. As a matter of fact, however, Chachrylion, in the opinion of Beazley and others, is closer to the "Epiktetan cycle" than is Euthymides, as the painters to whom his vases are referred are of the early severe red-figured period.

To American archæologists, the sections dealing with the frieze of the Erechtheum (why, by the way, does Casson spell it "Erechtheium?" Should it not be "Erechtheion" if the $e i$ is insisted upon?) will be of the greatest importance, in view of the long-projected publication of this temple by the American School of Classical Studies at Athens (Introduction, pp. 19-27, and Catalogue, pp. 174-218). Again, it is to be regretted that more of these fragments are not illustrated, and that Casson contents himself with referring his readers to the plates in the Antike Denkmäler, and the illustrations in the American Journal of Archoology and elsewhere. Casson adds nine new fragments to those previously identified, and rejects three others in his introduction that had previously been assigned to this frieze, while seven more which he includes in his catalogue (nos. 1169,1198 (a), 1236 (a), 1239 (a), 1301, 2627, and 4865) he considers doubtful. In writing this part of his book, Casson has been in constant communication and con- 
sultation with Director Hill of the American School of Classical Studies at Athens, whose opinion is frequently quoted, and always with the respect due to authority.

Especial notice should be given to the architectural terracottas, where the superiority of the Greek work to that done in Etruria is very evident. There is greater delicacy in detail and greater sureness of touch in the fragments of revetment here published (p. 289, no. 75, and p. 294, no. 109) than is found in the Etruscan work (for examples, see Luce and Holland, American Journal of Archoology, vol. XXII, 1918, pp. 319-339).

The catalogue of the terracottas is divided as follows: I, Human Figures; II, Protomai (Masks); III, Reliefs; IV, Architectural Fragments; V, Dolls; VI, Animals; VII, Miscellaneous Objects. Adequate descriptions are given of the most important specimens, and all objects from the same mould are grouped together. There are a number of photographs illustrating the principal types. For some of the groups of human figures, a "blanket description" is given, which covers the entire group. This is the most convenient way to handle such a large collection, as much needless repetition is thereby avoided.

This volume, as a whole, measures up in thoroughness, accuracy, and learning, to the high standard set by Dickins in his first volume. Nobody, in studying the sculptures of the Parthenon, for instance, can afford to be ignorant of Casson's introductory remarks as to the proper position of the slabs of the metopes and frieze, or the conclusions which can be drawn from the study of the pediment fragments (Introduction, pp. 1-11). It will take its place at once as a most useful, I was about to say indispensable, tool in the hands of any art student or archæologist who desires to refer to the contents of the Acropolis Museum, and its handy size will make it a convenient book for a visitor to the museum to consult on the spot. Thanks to the industry and scholarship of the British School, the Acropolis Museum has now been satisfactorily catalogued, so that, at last, all of its Greek sculpture, its terracottas, and its architectural fragments are available to those students who cannot go to Athens and see the museum itself. 